\title{
'n Kritiese beskouing van woordeboeke met geamalgameerde lemmalyste
}

D.J. Prinsloo, Departement Afrikatale, Universiteit van Pretoria, Pretoria, Suid-Afrika (danie.prinsloo@up.ac.za)

Opsomming: Die onlangs gepubliseerde Groot Woordeboek (Afrikaans en Nederlands), ook bekend as ANNA, is die eerste woordeboek met ' $n$ geamalgameerde lemmalys gebaseer op die model van Martin en Gouws (2000). ANNA baan ook die weg vir 'n soortgelyke benadering vir ander nouverwante tale soos die Sothotale en die Ngunitale van Suid-Afrika. Die voor- en nadele van vyf aspekte te wete (a) vergelyking en kontras, (b) gebruikersvriendelikheid, (c) ruimtebesparing, (d) ordening van betekenisonderskeidings en (e) die aanbod van 'n afsonderlike grammatikale kompendium word krities beskou. Die beginsels waarop amalgamering berus, die tersaaklike lemmatipes, asook enkele kenmerke van die model word vooraf kortliks bespreek.

Sleutelwoorde: GEAMALGAMEERDE LEMMALYS, VERWANTE TALE, OORTOLLIGHEID, ANNA, TWEETALIGE WOORDEBOEK, AFRIKAANS, NEDERLANDS, INLIGTINGSKOSTE, SISTEEMKOSTE

\begin{abstract}
A Critical Examination of Dictionaries with Amalgamated Lemmalists. The recently published Groot Woordeboek (Afrikaans en Nederlands), also known as ANNA, is the first dictionary with an amalgamated lemmalist based on the model of Martin and Gouws (2000). ANNA also paves the way for a similar approach for other closely related languages such as the Sotho languages and the Nguni languages of South Africa. The advantages and disadvantages of five aspects namely (a) comparison and contrast, (b) user-friendliness, (c) space saving, (d) ordering of senses and (e) provision of a separate grammatical compendium are critically evaluated. The principles of amalgamation, the relevant lemma types, as well as certain characteristics of the model are briefly discussed beforehand.
\end{abstract}

Keywords: AMALGAMATED LEMMALIST, RELATED LANGUAGES, REDUNDANCY, ANNA, BILINGUAL DICTIONARY, AFRIKAANS, DUTCH, INFORMATION COSTS, SYSTEM COSTS

\section{Inleiding}

Die doel van hierdie artikel is ' $n$ kritiese evaluering van woordeboeke wat vir naverwante tale soos Afrikaans en Nederlands, die Sothotale, en die Ngunitale saamgestel word met 'n enkele (geamalgameerde) lemmalys vir die verwante tale. Die onlangs gepubliseerde Groot Woordeboek (Afrikaans en Nederlands), 
voortaan benoem volgens die projek se eie identifikasie as ANNA, sal ontleed word as die hoofverwysingsbron. Die fokus is op die voor- en nadele van só 'n woordeboek met Afrikaanse en Nederlandse lemmas in 'n geamalgameerde lemmalys in vergelyking met twee afsonderlike woordeboeke of woordeboekdele Afrikaans-Nederlands en Nederlands-Afrikaans.

Die aard en samestelling van ANNA is omvangryk en dit is nie moontlik om binne die bestek van 'n artikel aan al die tersaaklike aspekte aandag te gee nie. In hierdie artikel word die fokus derhalwe beperk tot vyf aspekte, naamlik (a) vergelyking en kontras, (b) gebruikersvriendelikheid, (c) redundansie, (d) ordening van betekenisonderskeidings en (e) die aanbod van 'n afsonderlike grammatikale kompendium. (Uitvoerige besprekings van die aard en eienskappe van ANNA kan onder meer gevind word in Martin (2012a en 2012b), Martin en Gouws (2000), Marais (2011), Bosman (2013) en in die gebruiksaanwysings van ANNA.) Die artikel het ook ten doel om deur die analise van (a) tot (e) betreffende inligtingskoste en die model-/sisteemkoste van 'n geamalgameerde benadering, voorstelle aan die hand te doen hoe geamalgameerde woordeboeke meer gebruikersvriendelik gemaak kan word. Ten einde die argumente ten opsigte van (a) tot (e) in perspektief te plaas, word die beginsels waarop amalgamering berus, die tersaaklike lemmatipes, asook enkele kenmerke van die model vooraf kortliks bespreek.

\section{Die geamalgameerde model}

ANNA maak daarop aanspraak dat dit die eerste woordeboek is wat saamgestel is met 'n geamalgameerde lemmalys, dit wil sê een enkele lemmalys vir beide Afrikaans en Nederlands. 'n Woordeboek met 'n geamalgameerde lemmalys is in die eerste plek 'n vertaalwoordeboek wat vertaalekwivalente in die doeltaal vir woorde in die brontaal gee en omgekeerd. 'n Fundamentele verskil met tradisionele vertaalwoordeboeke is egter dat dit as gevolg van die geamalgameerde benadering ' $n$ kontrasterende woordeboek is wat die ooreenkomste en verskille tussen die betrokke tale op 'n meer direkte manier as afsonderlike woordeboeke, bv. Afrikaans-Nederlands en Nederlands-Afrikaans uitlig. Martin en Gouws (2000) en Martin (2012b) beklemtoon dit dan ook dat beide ooreenkomste en verskille op ' $n$ doeltreffende en kontrastiewe manier in ANNA uitgelig word.

The amalgamation model is not an explanatory model but a descriptive one. It aims to describe the lexemes of two languages in a bilingual dictionary in a directly contrastive way, contrary to the indirect way found in a traditional bilingual dictionary. (Martin 2012b: 413)

Die artikels van coffee, rain en motho in (1) vir 'n beplande geamalgameerde woordeboek Engels-Sotho/Sotho-Engels illustreer die twee aspekte van vergelyking/kontras en ruimtebesparing vir albei dele op 'n eenvoudige manier. 
(1)

coffee $n$. kofi

rain $n$. pula

motho $n$. a person, a human being

Vergelyking/kontras blyk uit die feit dat koffie, reën en mens in al drie die Sothotale dieselfde vertaalekwivalent het. Groot ruimtebesparing vind plaas deurdat elke artikel slegs een keer gelys word en nie drie keer soos wat dit in afsonderlike woordeboeke vir Sepedi, Setswana en Sesotho die geval sou wees nie. In gevalle soos (2) waar oorvleueling slegs ten opsigte van twee van die Sothotale voorkom vaar die model steeds goed ten opsigte van vergelyking/ kontras, maar die wins ten opsigte van ruimtebesparing is kleiner omdat verskillende vertaalekwivalente ter sake is en as sodanig gemarkeer moet word.

(2)

his $p p$. gagwe [Sep/Set], hae [Ses]

verb $n$. lediri [Sep/Set], leetsi [Ses]

In (2) word die lemmas his en verb steeds slegs een keer gelys maar verskil die vertaalekwivalent vir Sesotho (Ses) van dié van Sepedi (Sep) en Setswana (Set). In (3) lê die wins slegs op die vlak van vergelyking/kontras en die feit dat die lemma nie drie keer herhaal word nie. Daar is geen besparing ten opsigte van vertaalekwivalente nie deurdat die lemma in elkeen van die Sothotale anders vertaal word.

(3)

page $n$. letlakala ${ }_{[\mathrm{Sep}]}$, leqephe ${ }_{[\mathrm{Ses}}$, tsebe $_{[\mathrm{Set}]}$

In al hierdie voorbeelde, ongeag die beperkte omvang van die bewerking van die onderskeie lemmas, word die ooreenkomste en verskille, asook die besparing duidelik uitgebeeld. Dit is ook voor die hand liggend dat dit ' $n$ basiese vereiste en vertrekpunt vir die samestelling van woordeboeke met geamalgameerde lemmalyste is dat die tale aansienlik oorvleuel met betrekking tot die vorm en betekenis van die woorde. Bloot op sigwaarde ten opsigte van tekens (tokens) geneem, wys Gouws et al. (2004) op 'n groot oorvleueling met 'n hoë gebruiksfrekwensie tussen Afrikaans en Nederlands, soos in tabel 1 aangedui word.

Tabel 1: Afrikaans in vergelyking met Nederlands met frekwensies per miljoen woorde

\begin{tabular}{ccclccccc}
\hline Item & Afrikaans & Dutch & Item & Afrikaans & Dutch & Item & Afrikaans & Dutch \\
\hline van & 19688 & 18091 & niet & 46 & 7358 & als & 26 & 4011 \\
het & 15111 & 16655 & te & 8876 & 7025 & aan & 4338 & 3846 \\
een & 1892 & 16223 & die & 58733 & 6520 & of & 6653 & 3811
\end{tabular}




\begin{tabular}{lrrlrllll}
\hline en & 22516 & 13663 & met & 7139 & 6268 & nog & 1930 & 3507 \\
in & 15619 & 13483 & voor & 1316 & 6220 & wel & 276 & 3146 \\
is & 15628 & 11539 & maar & 3862 & 5121 & om & 7323 & 3074 \\
dat & 4841 & 9565 & ook & 3068 & 4414 & wat & 5268 & 2918 \\
op & 7132 & 8125 & dan & 907 & 4032 & kan & 2069 & 2488 \\
\hline
\end{tabular}

(Gouws et al. 2004: 798)

Vir die Sothotale het Prinsloo (2006) die 10,000 mees frekwente woorde in Sesotho, Setswana en Sepedi met mekaar vergelyk en bevind dat die woorde in dié tale tot 'n hoë mate oorvleuel. Die drie Sothotale het $19,4 \%$ woorde gemeen, Sepedi en Setswana deel 32,7\%, Sepedi en Sesotho 26,9\% en Setswana en Sesotho $34,4 \%$, figuur 1 .

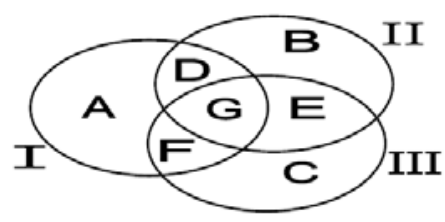

Figuur 1: Oorvleueling van Sepedi, Setswana en Sesotho ten opsigte van die 10,000 mees frekwente woorde $\mathrm{I}$ = Sepedi; II = Setswana; III = Sesotho

$\mathrm{A}=5$ 978; $\mathrm{B}=5$ 226; $\mathrm{C}=5$ 813; $\mathrm{D}=1333 ; \mathrm{E}=1$ 498; $\mathrm{F}=746 ; \mathrm{G}=$ 1943 (Prinsloo 2006: 199)

Dit lei tot ' $n$ enkele geamalgameerde lemmalys van 22,537 in vergelyking met 'n lys van 30,000 lemmas in drie afsonderlike woordeboeke, dus 'n besparing van byna $30 \%$.

\section{Lemmatipes in ANNA}

ANNA onderskei vyf tipes lemmas, naamlik (a) absolute kognate, (b) absolute kognate met verskillende vorme, (c) gedeeltelike kognate, (d) niekognate en (e) valse vriende, en hierdie vyf tipes lemmas vorm vervolgens die basis vir besinning in hierdie artikel.

Absolute kognate is Nederlandse en Afrikaanse woorde wat na vorm en betekenis identies is soos testament/testament, leemte/leemte en riool/riool. Absolute kognate met ' $n$ vormverskil het in albei tale dieselfde betekenis en die vormverskil is sodanig dat dit nie herkenbaarheid belemmer nie, byvoorbeeld gelijknamig/gelyknamig, leeglopen/leegloop en schoen/skoen. Gedeeltelike kognate staan teenoor absolute kognate deurdat hulle in minstens een betekenisonderskeiding verskil. So, byvoorbeeld, deel blijven en bly die betekenisonderskeiding 'nie weggaan nie' maar nie die Afrikaanse betekenis 'êrens tuisgaan' nie. 
Niekognate het dieselfde betekenis maar daar is ' $\mathrm{n}$ duidelike vormverskil soos keuken/kombuis, sinaasappel/lemoen, ens. Valse vriende is woorde wat vormlik ooreenstem maar verskillende betekenisse het, soos amper, verskoning en verskoon.

\section{Ooreenkomste en verskille: vergelyking en kontras}

Daar kan met die intrapslag onomwonde verklaar word dat ten opsigte van vergelyking en kontrastering van die naverwante tale, geamalgameerde woordeboeke, en ANNA in die besonder, volpunte kry ongeag die omvang van die artikels. Die uitwys van ooreenkomste en verskille lê die model ten grondslag en manifesteer op indrukwekkende wyses in die bewerking van beide Nederlandse en Afrikaanse lemmas, onder meer ten opsigte van vertaalekwivalente, betekenisonderskeidings, kollokasies en gebruiksvoorbeelde. Vergelyk byvoorbeeld die bewerking van die lemma ouderwets as ' $n$ eenvoudige maar tipiese voorbeeld in (4).

(4)

ouderwets bnw., ouderwets b.nw.

A|N (v. vroeger) ouderwets = ouderwetse kleren ouderwetse klere; een ouderwetse stoomtrein ' $n$ ouderwetse stoomtrein; ouderwetse opvattingen ouderwetse opvattings; hopeloos ouderwets hopeloos ouderwets $\neq$ stewige ouderwetse meubels oerdegelijk meubilair

N (net als vroeger) outyds, ouwêrelds = ouderwetse degelijkheid outydse deeglikheid; een ouderwetse winter ' $n$ outydse winter $\neq$ het was weer ouderwets gezellig dit was weer gesellig soos in die ou tyd

A (oulik; slim) bijdehand = ' $n$ ouderwetse kind een bijdehand kind

In die eerste plek behels die bewerking deurlopende vergelyking en kontras ten opsigte van vertaalekwivalente, betekenisonderskeidings en voorbeelde in drie gedeeltes, naamlik wat (a) Nederlands en Afrikaans gemeen het (A/N), (b) uniek is aan Nederlands (N) en (c) eie is aan Afrikaans (A). Die konvensies ' $=$ ' (is gelyk aan) en ' $₹$ ' (is nie gelyk aan nie) is kripties en funksioneel om ooreenkomste en verskille te merk. So, byvoorbeeld, wys die is-gelyk-aan-teken dat die betekenisonderskeiding 'in werking stel' in (9) in beide Nederlands en Afrikaans voorkom in voorbeelde soos de wasmachine aanzetten en die wasmasjien aansit, maar dat mens iemand in Afrikaans tot spoed aanspoor en nie soos in Nederlands aansit nie. Uitvoerige besprekings van die bewerking van die vyf lemmatipes kan gevind word in die voortekste van ANNA, Martin (2012a en 2012b), en Martin en Gouws (2000).

\section{Gebruikersvriendelikheid betreffende inligtingskoste en sisteemkoste}

Die geamalgameerde model is ' $n$ nuwe woordeboekkonsep wat verskil van die tradisionele tweetalige woordeboeke waaraan die gebruiker gewoond is. Hoewel daar uiteraard baie ooreenkomste met tweetalige woordeboeke is, moet die 
gebruiker besef dat dit ' $n$ unieke sisteem met sy eie kenmerke en voor- en nadele is. Wat betref gebruikersvriendelikheid kan gevra word wat die gebruiks- en sisteemkoste vir die gebruikers is. Die term sisteemkoste word in hierdie artikel gebruik om te verwys na die eienskappe, noodwendige vereistes en tekortkominge van die geamalgameerde model wat verband hou met wat Martin (2012b) "system side effects" en selfs "system pitfalls" noem. Sisteemkoste dui ook op wat David Lieb "cognitive overhead" noem en deur David Demaree gedefinieer word as "how many logical connections or jumps your brain has to make in order to contextualise the thing you are looking at" (Cognitive Overhead, Or Why Your Product Isn't As Simple As You Think (http: //techcrunch.com/2013/04/20/cognitive-overhead/)). Ter wille van goeie balans moet dit duidelik gestel word dat die leksikografiese benadering in sogenaamde tradisionele woordeboeke ook gebruiks- en sisteemkoste vir die gebruikers inhou. So, byvoorbeeld, vereis 'n alfabetiese ordeningsbenadering kennis van die alfabet, en uitspraakleiding met behulp van die IPA-ortografie kennis van fonetiese simbole. Die verskil is egter dat die meeste woordeboekgebruikers reeds met die tradisionele sisteem vertroud is, terwyl die geamalgameerde model van nuuts af bemeester moet word. Optimale gebruik van geamalgameerde woordeboeke veronderstel 'n groot mate van voorafkennis van die model/sisteem asook van addisionele woordeboekkonvensies.

Die toegangstruktuur van ANNA verskil in verskeie opsigte van ander woordeboeke en 'n voorvereiste vir optimale gebruik is dat die gebruiker eers deeglike voorafstudie sal moet doen van die uitleg, konvensies, teksgedeeltes, kruisverwysingstelsel, ens. wat in die woordeboek gebruik word. Hierdie vereiste is in beginsel ' $n$ nadeel omdat dit bekend is dat gebruikers oor die algemeen nalaat om die gebruikersgids van 'n woordeboek te raadpleeg, om nie van intensiewe bestudering daarvan te praat nie. So, byvoorbeeld, meld Bosman (2013: 48) dat geeneen van die studente wat aan 'n gebruikerstudie van ANNA deelgeneem het, die voortekste gelees het nie.

Die vooraforiëntering vir die gebruik van ANNA lê ook op meer as een vlak. Die belangrikste is begrip van die gebruik van simbole soos A (Afrikaans), N (Nederlands), N/A (Nederlands en Afrikaans), = (Nederlands dieselfde as Afrikaans), $\neq$ (Nederlands verskillend van Afrikaans), dat alle teksgedeeltes wat op Afrikaans betrekking het, kursief gedruk is en alle Nederlandse teks in romeinse letters aangebied word, ens. Dit is dan ook belangrik dat die samestellers geen foute begaan in die rigtinggewende voorbeelde in die gebruiksaanwysings soos die foutiewe Nederlandse spelling (p. 27) binne die Afrikaanse frase "bek van ' $n$ trechter trechtermond" in plaas van "bek van ' $n$ tregter trechtermond" nie.

'n Tweede vlak behels studie van die gebruiksaanwysings ten opsigte van (a) die algemene aard van die woordeboek, (b) amalgamasiemodel en die tipes trefwoorde, (c) bou en struktuur van die artikels, (d) behandeling van voorbeelde en verbindings, (e) verwysings, (f) agtertekste en (g) ander aspekte soos 
metataal, volgordekwessies, ens. wat uitvoerig in die gebruiksaanwysings beskryf word.

'n Derde vlak behels kennis van inherente kenmerke van die sisteem soos die aanbod en ordening van ekwivalente en betekenisonderskeidings wat hieronder in meer detail bespreek word.

Die gebruiksaanwysings is omvangryk en beslaan 18 bladsye en eindig met baie belangrike gebruiksinligting ten opsigte van artikeluitleg in figuur 2 .

Die gebruik van ANNA vereis dus veel meer van die gebruiker as bloot die kennis van standaardwoordeboekkonvensies waaroor die gemiddelde gebruiker beskik ten einde die inligting te vind en maksimaal daarby te kan baat. Bosman (2013) gebruik die terme toegangsgemak en leksikografiese inligtingskoste in dié verband. Wat inligtingskoste betref, bespreek sy die aangeleentheid uitvoerig aan die hand van gebruikerstudies en bevind dat die respondente in die algemeen nie daarin geslaag het om die gevraagde inligting maklik en vinnig te kon vind nie. Sy kom tot die gevolgtrekking dat die "inligtingskoste nogal hoog is" en dat studente ' $n$ volledige voorafdemonstrasie benodig:

Gemeet aan Hartmann en James (1998) se definisie ("the relative ease with which information can be located in a reference work") dui die bogenoemde ondersoekdata en ontleding daarop dat die inligtingontsluitingsproses nóg vinnig nóg maklik was. ... Sowel soekverwante as begripsverwante koste is aan die hoë kant. (Bosman 2013: 51)

Dit is te verstane dat 'n nuwe woordeboekmodel eiesoortige toegangsvereistes en -konvensies sal hê en verder dat daar volgens Martin (2012b) ook sekere noodwendige "system side effects", oftewel sisteemkoste sal wees wat meer voorafkennis, voorafstudie en begrip van die teikengebruiker sal verlang. Dit is belangrik dat onderskeid gemaak moet word tussen sisteemkoste as eienskappe en vereistes wat inherent aan 'n woordeboekmodel is en waaroor die leksikograaf eintlik geen beheer het nie, en sisteemkoste as wyses waarop die leksikograaf wel die gebruiker ter wille kan wees om die woordeboek meer gebruikersvriendelik te maak. So, byvoorbeeld, moet die samestellers dit oorweeg om die artikeluitleg in figuur 2 op ' $n$ baie meer prominente plek aan te bied - verkieslik heel voor in die woordeboek - en die voorteks te stratifiseer ten opsigte van byvoorbeeld noodsaaklike gebruiksinligting versus kenmerke van en verdere inligting oor die model. Kennis van die gebruiksinligting in figuur 2 moet genoegsaam wees vir aanvanklike gebruik van die woordeboek tot tyd en wyl die gebruiker meer vertroud raak met die model.

\section{Ruimtebesparing en redundansie}

Soos wat hierbo ten opsigte van ' $\mathrm{n}$ geamalgameerde benadering vir die Sothotale opgemerk is, is die veronderstelling van die geamalgameerde benadering dat dit redundansie sal verminder op sowel makro- as mikrostruktuurvlak. 


\section{Artikeluitleg (Afrikaans)}

\begin{abstract}
Algemeen: Nederlandse inligting (trefwoorde, grammatikale gegewens, betekenisonderskeidings, voorbeelde, vertalings) is deurgaans romeins gedruk, Afrikaanse inligting kursief. Bykomende inligting oor altyd in Afrikaans gegee en is dus kursief gedruk.
\end{abstract}

Vir meer inligting kan ook die

Gebruiksaanwysings en die lys Gebruikte afkortings, merkers en simbole geraadpleeg word.

Nederlandse trefwoorde word in vet romeinse druk en Afrikaanse trefwoorde in vet kursiewe druk aangegee.

Boskrifnommers word gebruik om te onderskei tussen woorde wat eenders gespel word maar tot ververskil to.v. betekenis.

$\mathrm{A} / \mathrm{N}$ in die kantlyn dui aan dat die daaropvolgende betekenis(se) in Afrikaans sowel as in Nederlands voorkom. Waar meerdere betekenisonderskeidings voorkom, word die in sirkeltjies genommer.

A of $\mathrm{N}$ in die kantlyn dui aan dat die daaropvolgen betekenis(se) uitsluitlik in Afrikaans of Nederlands onderskeidelik voorkom.

Valse vriende, d.w.s woorde wat in Afrikaans en Nederlands (nagenoeg) dieselfde vorm het maar sterk van betekenis verskil, word deur ' $n$ spesiale simbool II aangedui.

Trefwoorde word gevolg deur woordsoortinligting, met direk daarna bykomende grammatikale inligting tussen vierkantige hakies.

Kort betekenisomskrywings en vertaalekwivalente word in vet druk gegee, Nederlands in romeinse en Afrikaans in kursiewe druk.

'n Isgelykaanteken (-) dui aan dat die daaropvolgende voorbeeld(e) in die twee tale ooreenstem.

'n Isongelykteken dui aan dat er 'n relevante verskil is tussen voorbeeld(e) en vertaling(e)

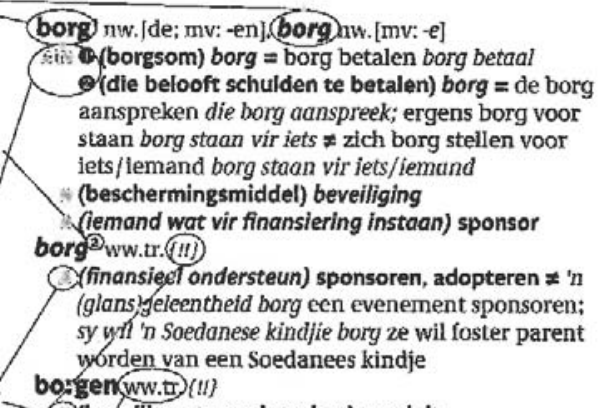
aanspreken die borg aanspreek; ergens borg voor staan borg staan vir iets $\neq$ zich borg stellen voor iets/lemand borg staon vir iets/iemund

* (beschermingsmiddel) beveiliging (iemand wat vir finansiering instaan) sponsor borg ${ }^{2}$ ww.tr. (III)

QV(inansied ondersteun) sponsoren, adopteren $\neq 1 n$ (glans)geleentheid borg een evenement sponsorem: sy yol' 'n Soedanese kindjie bory ze wil foster parent yorden van een Soedanees kindje

bosgen(ww. प) $(u)$

(3) (beveliligen tegen losraken) vassluit

boom nw. [de; mv: bomenl, boom nw. [mv: bome]

wiN (grote plant met stevige stam) booñ $=$ de boom van kennis (van goed en kwaad) die boom von

van kennis (van goed en kwaad) die boom von
kennis (von goed en kwaad) $\Xi$ <ig.> de kat uit de kennis (vgh goed en kwaad) () fig.> de kat uit d
boom k4jken die kat uit die boom kyk; ‘fig.) boormpje groot, plantertije dood boomple groot, plantertile dood $\neq<4$ g. een boom van een vent ' $n$ berg van 'n kêrel/ n blok van 'n man, 'n yslike kêrel; fig. je kunt de boom in! jy kan gaan boomkliml; <iig.> hoge bomen vangen veel wind hoë bome vang die meeste wind; <fig.> door de bomen het bos nilet zlen deur/vanwe gleer sien nie; <tig.> aan de vruchten kent men de

boom 'n mens ken die boom aan sy vrugte; <fig.' oude bomen verplant men niet 'n ou boom verplant nie maklik nie/kun nle maklik verplont word nic $x$ flg $>$ die appel vol nie ver van dh giezo vader, zo zoon, de appel valt niet ver van de stam/boom; <fig.> tussen die boom en die bas wees weifelachtig zijn, noch het een noch het ander zijn; < sics > buig die boomple terwyl by nog jonk is

Punthakies word gebruik vir etikette wat bykomen-_ Jonge rij zen kan men buigen (maar oude bomen de inligting verskaf. niet); <fig. > dit gaat maar tussen die boom en die bas het gaat maar matig

By sommige trefwoorde staan 'n verwysing, of na____ battepis nw. (zie)boter nw. ' $n$ ander trefwoord (deurgaans van Afrikaans na

Nederlands), of na die grammatikale kompendium.

'n Verwysing wat op ' $n$ koppelteken eindig, verwys na

'n woorddeel. Derglike verwysings wat in 'n grys balk

gedruk staan, dien as bykomende hulpmiddel by die

opsoek van woorde waarna gesoek word.

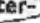

Figuur 2: Gebruiksinligting ten opsigte van artikeluitleg in ANNA

Op die vlak van die makrostruktuur word veronderstel dat die redusering van 
twee of meer lemmalyste na een noodwendig tot ruimtebesparing sal lei en nie gebruikersonvriendelik sal wees nie. Hierdie veronderstelling vorm die belangrikste motivering in Prinsloo (2006) vir die gebruik van die model:

A bidirectional English $\rightarrow$ \{siSwati, isiXhosa, isiNdebele and isiZulu\}, \{siSwati, isiXhosa, isiNdebele and IsiZulu $\rightarrow$ English dictionary is comparable to four bidirectional bilingual dictionaries, English-siSwati, siSwati-English, EnglishisiXhosa, isiXhosa-English, English-isiZulu, isiZulu-English, and English-isiNdebele, isiNdebele-English. Thus two directions for the envisaged model versus eight sides for separately bridging English and a Nguni language. (Prinsloo 2006: 195)

Prinsloo (2006) aanvaar ook sonder meer dat die omvang van ruimtebesparing groot is in gevalle soos (1) waar dieselfde lemma in al drie die Sothotale gebruik word, en steeds bydra tot besparing waar 'n lemma minstens twee tale verteenwoordig soos in (2).

Dieselfde veronderstelde ruimtebesparing geld ook vir 'n AfrikaansNederlands geamalgameerde lemmalys. Martin (2012b: 418) stel dit onomwonde: "amalgamation reduces redundancy" (sy kursivering). Daar kan egter geargumenteer word dat faktore soos die noodwendige afsonderlike lysting van sekere Afrikaanse lemmas asook eise aan die voorafkennis van die gebruiker, óf redundansie in die hand werk óf gebruikersonvriendelik is. Hierdie faktore moet derhalwe as debiete teen ruimtebesparing in die model verreken word.

Die omvang van ruimtebesparing wissel uiteraard vir die verskillende lemmatipes (a) tot (e) wat in ANNA onderskei word. In die geval van absolute kognate wat vormlik identies is en gedeeltelike kognate, is ruimtebesparing ' $n$ gegewe deurdat slegs een lemma gelys hoef te word. Vir niekognate noodsaak die vormverskil afsonderlike lemmatisering en is daar nie ruimtebesparing nie. In ANNA word valse vriende afsonderlik gelemmatiseer en gevolglik word ruimte ook nie bespaar nie. Die laaste kategorie, absolute kognate met 'n vormverskil, lewer gemengde resultate. Martin (2012b: 417) gaan van die standpunt uit dat die vormverskille wat hulle vertoon klein genoeg is sodat hulle maklik herkenbaar is en noem hartinfarkt/hartinfark, stikken/stik as voorbeelde.

Die redaksionele beleid is om nie die Afrikaanse lemma op te neem indien die Afrikaanse lemma die Nederlandse lemma alfabeties direk sou volg of voorafgaan, of hoogstens deur sewe items van mekaar geskei is nie. So, byvoorbeeld, word die Afrikaanse lemmas erupsie en versmal nie afsonderlik gelemmatiseer nie omdat dit die Nederlandse lemmas eruptie en versmallen respektiewelik alfabeties direk sou voorafgaan. Dieselfde geld vir die Afrikaanse lemmas holoog en onfatsoenlik wat alfabeties op enkele lemmas na, die Nederlandse lemmas hologig en onfatsoenlijk volg. Indien die betrokke lemmas alfabeties verder as sewe items van mekaar voorkom, word die Afrikaanse lemma ooreenkomstig ANNA se redaksionele beleid wel in die toepaslike alfabetiese posisie gelys met 'n kruisverwysing na die Nederlandse lemma soos in (5) en (6)(a). 
(5)

skrei zie schreien

skriba zie scriba

skrif zie schrift

skrif- zie ook schrift-

skrik ${ }^{1}$ nw. zie schrik nw.

$s k r i k^{2}$ ww. zie schrikken ww.

skrik- zie (ook) schrik-

(6)

(a) neerskryf zie neerschrijven

(b) neerschrijven ww.tr., neerskryf ww.tr.

A|N (opschrijven) neerskryf \# je belevenissen in een schrift neerschrijven jou belewenisse in 'n notaboek opteken

Die redaksionele beleid word egter nie streng gevolg nie. In die geval van (6)(a) word die Afrikaanse woord wel as lemma opgeneem hoewel dit slegs vier alfabetiese posisies na (6)(b) verskyn. Hierteenoor is die Afrikaanse lemma bekyk wat alfabeties meer as 70 lemmas verwyderd van bekijken sou wees, nie opgeneem nie. Dieselfde geld vir geskei wat, indien dit gelemmatiseer sou wees, 65 lemmas verwyder van gescheiden in die woordeboek sal wees. Omdat geskei nie opgeneem is met 'n kruisverwysing na gescheiden nie, sal die gebruiker nie weet om onder gescheiden te soek nie. Dieselfde geld vir krygsraad wat ook etlike bladsye verwyder is van die alfabetiese posisie vir krijgsraad. Die probleem by laasgenoemde twee voorbeelde lê onder meer daarin dat die onderskeid in spelling "vroeg" in die woord d.w.s binne die eerste 3-5 karakters voorkom. In ander gevalle soos byvoorbeeld brandstichting versus brandstigting, geruststellen versus gerusstel en ommuren versus ommuur waar die verskille later in die woord voorkom, is die gebruiker se kanse veel beter om wel die lemma te vind.

Die aanbod van ' $n$ afsonderlike grammatiese kompendium noodsaak verdere kruisverwysings wat ook redundansie in die hand werk.

Die vraag is dus of die regte balans hier gevind is ten opsigte van ruimtebesparing en gebruikersvriendelikheid.

Op die vlak van die mikrostruktuur word eweneens veronderstel dat die redusering van twee lemmalyste na een, noodwendig tot ruimtebesparing sal lei. Martin (2012b: 407) bied gepas die bewerkings van robot ter illustrasie in (7) en (8).

In the Dutch-Afrikaans part:

robot

(automaat die arbeid verricht) [automaton carrying out work] robot, blikman 
In the Afrikaans-Dutch part:

robot

(paal met lig wat verkeer reël) [pole with light regulating traffic] stoplicht, verkeerslicht (outomaat wat werk verrig) [automaton carrying out work] robot

(8)

In ANNA the information from the two parts is brought together, amalgamated, resulting in an entry like this:

robot/robot

A/N (automaat die arbeid verricht) robot, blikman

A (paal met lig wat verkeer reël) stoplicht, verkeerslicht

Indien die Engelse vertalings buite rekening gelaat word, beteken dit dat ANNA in (8) in 17 woorde vermag wat in 21 woorde in tradisionele tweetalige woordeboekformaat nodig sou wees. In hierdie spesifieke geval is dit 'n $19 \%$ besparing.

Ten opsigte van die A/N artikels kan 'n sterk saak uitgemaak word ten gunste van besparing deurdat inligting slegs een keer gegee word waar dit in die geval van 'n tweerigtingwoordeboek (N-A, A-N) twee keer aangebied sou word.

Die vraag is egter tot watter mate die afsonderlike N- en A-gedeeltes ruimtebesparing in die hand werk omdat die tale dan wel afsonderlik bewerk word. So, byvoorbeeld, sou die $\mathrm{N}$ - en A-gedeeltes in (4) in die N-A- en A-N-kant van ' $n$ tweerigtingwoordeboek aangebied word en derhalwe nie tot ruimtebesparing in die geamalgameerde model lei nie. Vergelyk ook die artikels in (9) met dié in (10) en (11) ten opsigte van die aanbod en ordening van betekenisonderskeidings in 'n geamalgameerde model versus afsonderlike bewerkings in twee verklarende woordeboeke vir Afrikaans en Nederlands ten opsigte van die omvang van die artikels.

(9)

aanzetten $^{1}$ ww.intr., aansit ww.intr.

A|N O (dik maken) aansit $\neq$ pinda's zetten erg aan grondboontjies laat jou baie gewig aansit $\neq$ vyf kilogram (gewig) aansit vijf kilo aankomen

o (ongewenst naderbij komen) aansit $\neq<$ inf.> daar kwam de ME aanzetten daar kom die onlustepolisie toe aangesit; laat/vroeg komen aanzetten laat/vroeg aangesit $k o m \neq<$ fig., inf.> daar kom je nu mee aanzetten vir wat kom jy nou daarmee aangesit? $\neq<$ fig. $>$ met iets aangesit kom met iets komen aandragen, met iets komen aandraven

aanzetten $^{2}$ ww.tr., aansit ww.tr.

A|N O (vastmaken aan iets) aansit, vaswerk, aanwerk, insit = knopen aan een jas zetten knope aan ' $n$ jas aanwerk $\neq$ mouwen aan een jas aanzetten moue aan ' $n$ jas/baadjie insit, moue aan ' $n$ jas aansit $\neq<$ fig.> iemand de duimschroeven aanzetten iemand laat bontstaan (2) (in werking stellen) aansit $\neq$ de wasmachine aanzetten die wasmasjien aansit $\neq$ die lig aansit het licht aandraaien; die enjin/motor aansit de motor/auto starten

$\mathrm{N}$ - (aansporen tot (iets)) aanspoor, opstook $=$ hij zette mij aan tot spoed hy het my tot spoed aangespoor $\neq$ iemand ergens toe aanzetten iemand opstook om iets te doen

o (nadruk geven) beklemtoon $\neq$ lippen aanzetten lipstiffie aansmeer 
B (scherper maken) slyp = een mes aanzetten ' $n$ mes slyp

(4 (beginnen iets te doen) begin $\neq$ de sprint aanzetten die pas begin versnel (in ' $n$ fietswedren)

A (aan die liggaam sit) omdoen, aanleggen $=$ ' $n$ verband aansit een verband aanleggen; ' $n$ ander das aansit een andere das omdoen $\neq$ 'n skoon doek vir die baba aansit de baby een schone luier omdoen; ' $n$ kind aan die bors sit een kind (aan de borst) aanleggen; vir die kind ' $n$ borslap(pie) aansit het kind een slabbetje omdoen, het kind een slabbetje voordoen

\section{(10) e-HAT}

\section{aan'sit ww. [aangesit]}

1 Aan, by iets sit: Al die gaste moet nou aansit aan die groot tafel.

2 Aanwerk, vasheg, voorsien van: Nuwe knope aan 'n hemp aansit. 'n Nuwe steel aan 'n graaf aansit.

3 Aan die gang sit: Die motor aansit.

4 Aan die werk sit: Die span werkers aansit om te skoffel.

5 Opwerk, aanhits: Mense tot opstand aansit.

6 Bykry: Gewig, vet aansit.

7 (<Eng.) Jou baie verbeel; spog, voorgee.

aansit: $\sim$ motor, $\sim$ sleutel. aansitterig

\section{(11) Van Dale Groot Woordenboek}

\begin{tabular}{|c|c|}
\hline $\begin{array}{l}\text { aan'zet·ten }{ }^{1} \\
\text { zie ook: aanzetten tot } \\
\text { onovergankelijk werkwoord }\end{array}$ & $\begin{array}{l}\text { aan·zet·ten }{ }^{2} \\
\text { zie ook: aanzetten tot } \\
\text { overgankelijk werkwoord; zette aan, heeft aangezet }\end{array}$ \\
\hline $\begin{array}{l}1 \text { zette aan, heeft aangezet } \\
\text { dik maken } \\
\text { betekenisverwante termen }\end{array}$ & $\begin{array}{l}1 \text { ook absoluut } \\
\text { beginnen (iets te doen) } \\
\text { betekenisverwante termen }\end{array}$ \\
\hline $\begin{array}{l}2 \text { zette aan, is aangezet } \\
\text { licht aanbranden } \\
\text { betekenisverwante termen }\end{array}$ & $\begin{array}{l}2 \text { (iets) aan een voomerp vastmaken } \\
\text { betekenisverwante termen } \\
\text { context }\end{array}$ \\
\hline $\begin{array}{l}\text { Tा idioom } \\
\quad \text { komen aanzetten met iets } \\
\text { aankomen met een verzoek, een verhaal enz.; een voorwerp } \\
\text { aanbrengen zonder dat dit gewenst of verwacht wordt }\end{array}$ & $\begin{array}{l}3 \text { inschakelen } \\
4 \text { benadrukken } \\
\text { context } \\
\text { betekenisverwante termen } \\
\text { (iets) zo plaatsen dat het bijna aan iets anders raakt } \\
6 \text { scherpen, wetten } \\
\text { betekenisverwante termen } \\
\text { context }\end{array}$ \\
\hline
\end{tabular}

Die aanbod en ordening van ekwivalente en betekenisonderskeidings betreffende sisteemkoste

Martin (2012b: 420) stel dit duidelik dat die geamalgameerde benadering sekere neweaspekte het wat eie is aan die sisteem. Hy verwys daarna as "system side 
effects". Só word die aanbod van vertaalekwivalente en die ordening van betekenisonderskeidings deur die sisteem self bepaal en nie deur byvoorbeeld frekwensie van voorkoms van betekenisse nie. In gevalle waar Afrikaans en Nederlands dieselfde vertaalekwivalent het, kry dié paar in ANNA voorkeur, al sou daar 'n meer gebruiklike woord in Afrikaans bestaan. Martin (2012b: 420) noem taxateur/taksateur as voorbeeld waar taksateur as vertaalekwivalent bo die meer gebruiklike waardeerder verkies word.

taxateur nw. [de; mv: -s], taksateur nw. [mv: -s]

A|N (iemand die waarden van zaken bepaalt) $<$ form..$>$ taksateur, waardeerder $=$ een taxateur benoemen ' $n$ taksateur benoem, ' $n$ waardeerder benoem; een beëdigd taxateur ' $n$ beëdigde taksateur

Alhoewel waardeerder in die $\mathrm{A} / \mathrm{N}$-gedeelte teregkom, is daar geen aanduiding vir die gebruiker dat waardeerder by verre die gebruiklikste vorm in Afrikaans is nie. So, byvoorbeeld, dui 'n soektog in die Media24 Argief vir die koerant Beeld daarop dat taksateur slegs in een berig voorgekom het teenoor 264 berigte waarin waardeerder voorkom. Die feit dat waardeerder nie in die sisteem as hoofbetekenis uitstaan nie, kan as 'n debiet betreffende sisteemkoste beskou word.

Die ordening van betekenisonderskeidings word ook deur die geamalgameerde sisteem dikteer. Die betekenisonderskeidings wat Afrikaans en Nederlands gemeen het, word eerste gegee, gevolg deur dié wat eksklusief is vir Nederlands en dan dié wat eksklusief Afrikaans is. So, byvoorbeeld, word in die bewerking van ei/eier, 'vrouwelijke geslachtscel' as eerste betekenisonderskeiding aangebied terwyl die tweede betekenis 'legsel v. bepaalde dieren, bv. vogels' by verre die hoofbetekenis vir eier in Afrikaans is. Bestudering van korpusdata dui daarop dat $93 \%$ van die gebruik van eier die tweede betekenisonderskeiding in (13) is en eier as 'vroulike geslagsel' slegs 7\% van die gebruik uitmaak.

ei nw.[het; mv: -eren], eier nw. [mv:-s]

A|N O (vrouwelijke geslachtscel) eier $=$ een bevrucht eitje ' $n$ bevrugte eiertiie; het eitje in de baarmoeder die eiertjie in die baarmoeder

o (legsel v. bepaalde dieren, bv. vogels) \{Opm.: In Afr. kom die woord 'ei' ook in dié betekenis voor, maar slegs in die uitdrukking 'vir' 'n appel en ' $n$ ei'.\} eier = een ei leggen ' $n$ eier lê; een ei uitbroeden ' $n$ eier uitbroei; de eitjes van insecten die eiertjies van insekte $=<$ fig.> voor een appel en een ei vir ' $n$ appel en ' $n$ ei

Dus kan ook ten opsigte van die ordening van betekenisonderskeidings beweer word dat die sisteemkoste hoog is met betrekking tot gebruikersinligting omdat die gebruiker nie kan sien watter betekenisonderskeiding die mees frekwente een is nie.

Meer problematies is gevalle waar die hoofbetekenis van bepaalde Afrikaanse lemmas nie aangebied word nie, soos byvoorbeeld by kaal/kaal en aanzetten/aansit in (14) en (9). 
(14)

kaal bnw., kaal b.nw.

A|N O (arm(oedig)) kaal $\neq$ een kale boel/bedoening/ontvangst ' $n$ power spul/toestand/verwelkoming $\neq<$ fig.> hoe kaler, hoe royaler hoe kaler, hoe rojaler, hoe kaler jonker, hoe groter pronker, hoe kaler jakkals, hoe groter stert; <fig.> een kale neet ' $n$ kaal jakkals; <fig.> zo kaal als een luis so kaal soos 'n luis; <fig.> zo kaal als een kerkrat/neet so kaal soos ' $\mathrm{n}$ kerkmuis/neet; <fig., vero.> een kale juffer ' $n$ onbemiddelde dame wat haar deftig voordoen; <fig.> kale kak pure aanstellery/snobisme; <fig.> kale drukte ' $n$ ophef oor niks $\neq$ kaal uitgetrek agterbly/terugkom berooid achterblijven/terugkeren $\neq<$ <ig.> iemand kaal uittrek iemand kaalplukken; <fig.> iemand rot en kaal steel iemand uitschudden

o (onbegroeid, onbedekt) kaal, bles, bleskop, haarloos = kale bomen/muren kaal bome/mure; iets kaal vreten iets kaal vreet $\neq$ een kale deur ' $n$ ongeverfde deur; je kaal laten knippen/scheren jou kop kaal laat knip/skeer; een kaal hoofd ' $n$ kaal kop, 'n bleskop; een kale man ' $n$ man met ' $n$ bles, ' $n$ kaalkopman; een kale plek ' $n$ kaal kol, ' $n$ bles $\neq<$ fig.> de kale huur die basiese huur; <fig.> kaal worden/zijn bles word/wees, deur jou hare groei, kaal word/wees (bv. deur blare te verloor); <fig.> zo kaal als een biljartbal/knikker zijn totaal kaalkop wees, heeltemal bles wees $\neq$ met ' $n$ kaal bolyf met ontbloot bovenlijf; kaal sonaanbidders ontblote zonaanbidders; kaal arms/bene blote armen/benen; sonder sy serpie voel hy so kaal zonder zijn sjaaltje voelt hij zich zo naakt; kaal rotse naakte rotsen; kaal nael flitsen, streaken; kaal rondloop naakt rondlopen; kaal swem naaktzwemmen $\neq<$ fig.> iemand met jou oё kaal uittrek iemand de kleren van het lijf kijken

In die geval van kaal/kaal sorg die ordening van die betekenisonderskeidings 1. "arm(oedig)" en 2. "onbegroeid, onbedekt" dat daar geen prominensie aan die Afrikaanse hoofbetekenis "sonder klere" gegee word nie. Die eerste vermelding van kaal in dié betekenis word aan die einde van die tweede betekenisonderskeiding gemaak. Aangesien die artikel redelik lank is, dra dit daartoe by dat die Afrikaanse hoofbetekenis maklik misgekyk kan word. Die gebruiker wat Nederlands ken, en kaal opsoek, vind dus nie sonder meer die hoofbetekenis van kaal in Afrikaans as "sonder klere" nie. Volgens korpusdata verteenwoordig laasgenoemde betekenis ruim $50 \%$ van die gebruik van kaal. eHat gee wel die nodige prominensie deur dit as die eerste betekenisonderskeiding aan te bied. Vergelyk (15).

\section{(15) eHat}

kaal b.nw., bw.

1(a) Sonder klere aan die lyf; naak ... (b) Sonder klere aan 'n gedeelte van die liggaam ...

Net so word die hoofbetekenis van aansit, te wete 'by iets, bv. ' $n$ tafel aansit', nie aangegee nie, selfs nie eers in die A-gedeelte (sien (9) hierbo) wat spesifiek op Afrikaans afgestem is nie. Ook in hierdie geval dui korpusanalise op 'n $28 \%$ gebruik van aansit as "by iets, bv. 'n tafel aansit" gevolg deur 20\% "aanwerk/ aanheg/vasheg", 17\% "aanskakel", 15\% "gewig optel/aansit" met 'n opmerklike $12 \%$ van die gebruik vir die uitdrukking ore aansit. (Laasgenoemde verdien sekerlik vermelding as gebruiksvoorbeeld in Afrikaanse woordeboeke.) eHat se betekenisonderskeiding 1 en 2 in (10) is dus nommerpas, en by 1 word ook die 
mees tipiese gebruiksvoorbeeld, naamlik om by ' $n$ tafel aan te sit, gegee.

Benewens bogenoemde gevalle waar die mees frekwente betekenis nie eerste gelys of as sodanig markeer word nie, en gevalle waar die hoofbetekenis glad nie gelys word nie, moet die sisteemkoste ook bereken word vir die gevalle soos vaak/vaak, bestellen/bestel, en bakkie/bakkie waar duidelike betekenisoorvleueling maar ook belangrike betekenisverskille voorkom. Dit behels die lemmatisering en bewerking van polisemiese lemmas wat vormlik ooreenkom maar in een of meer betekenisonderskeidings verskil. Dit kan ook 'n valsevriende-verhouding impliseer. Gedeeltelike kognate is problematies en vra om 'n komplekse hantering.

ANNA lemmatiseer en bewerk wel Nederlandse en Afrikaanse woorde wat slegs vormlik ooreenstem en geen enkele betekenisonderskeiding in gemeen het nie, as valse vriende. Gevalle soos verskoon, verskoning en amper/ amper word in ANNA as valse vriende hanteer. Vergelyk (16) en (17) vir verskoning en amper.

verskoning nw. [mv: verskonings] \{!!\}

A O (apologie) excuus $\neq$ verskoning maak/aanbied je excuus/excuses maken/aanbieden, je verontschuldigingen aanbieden/maken/uiten; by jou vriende verskoning maak je bij/ tegenover je vrienden verontschuldigen; (om) verskoning vra vir jou gedrag je verontschuldigen voor je gedrag, je excuseren voor je gedrag

o (ekskuus, uitvlug) smoes, uitvlucht, excuus = verskonings soek/vind uitvluchten zoeken/vinden; ' $n$ geldige/goeie verskoning hê een geldig/goed excuus hebben $\neq$ ' $n$ swak/ flou verskoning een slap/mager excuus; iets as verskoning gebruik iets als excuus aanvoeren/gebruiken; ' $n$ verskoning om na die bottel te gryp een alibi om naar de fles te grijpen; ' $n$ verskoning versin/uitdink een uitvlucht verzinnen; as verskoning (aanvoer dat ...) ter verontschuldiging (aanvoeren dat ...); verskonings! verskonings! allemaal smoesjes!

- (kennisgewing $v$. afwesigheid) afzegging \# verskoning aanteken verstek aantekenen; ondanks die baie uitnodigings is daar nog net drie verskonings ondanks de vele uitnodigingen zijn er nog maar drie afzeggingen

amper1 bw. \{!!Opm.: In Afr. is 'amper' en 'byna' sinoniem. \}

A (net nie/byna) bijna, haast $\neq$ dit het amper/haas onbetaalbaar geword het is haast onbetaalbaar geworden; ' $n$ mens kan amper(s) nie jou oë glo nie je gelooft haast niet wat je ziet; so ampertjies in/net-net oor centimeters naast/over $\neq<$ fig.> amper, maar nog nie stamper nie bijna maar niet helemaal

amper $^{2}$ bw. \{!!Opm.: In Ned. is 'amper' en 'nauwelijks' sinoniem.\}

N (nauwelijks) net-net, nouliks ₹ hij verdient amper genoeg om rond te komen hy verdien nouliks genoeg om uit te kom; hij kan amper bij de bovenste plank hy kan net-net by die boonste rak bykom

Eenvoudig gestel, kan gesê word dat iemand wat amper ' $\mathrm{n}$ doel bereik het in Nederlands net-net daarin geslaag het, maar in Afrikaans net-net misluk het. Dit is die taak van die leksikograaf om duidelike gebruikersleiding ten opsigte van valse vriende te gee en die keuse van dubbele uitroepingstekens "!!" as merker in (16) en (17) suggereer die belangrikheid van die verskille. In (16) is 
Afrikaans en Nederlands valse vriende met betrekking tot al drie die betekenisonderskeidings. ANNA se benadering tot valse vriende verskil van die een wat deur Gouws et al. (2004) voorgehou word, naamlik dat valsevriende-verhoudings ook as sodanig bewerk moet word in gevalle waar polisemiese woorde in minstens een betekenisonderskeiding in ' $n$ valsevriende-relasie tot mekaar staan. Hulle is ook van mening dat gebruikers spesifieke leiding in dié verband moet kry:

When speakers of either Afrikaans or Dutch consult a bilingual Afrikaans/Dutch// Dutch/Afrikaans dictionary to retrieve information regarding the respective Dutch or Afrikaans lexical items bestellen and bestel they need guidance to warn them that although the items in both languages have the sense 'to order', only the Dutch item has the sense 'to deliver'. (Gouws et al. 2004: 802)

Vergelyk (18) en (19).

bakkie s.nw. (-s) 1 v.v.! Ligte vragmotor: Ons laai die tuinvullis sommer self op die $\sim$ en neem dit na die stortingsterrein. 2 'n Klein houer: Ma sit my toebroodjies soggens in 'n plastiese . Verkleinwoord van bak.

Gouws et al. (2004: 798) gebruik die merker "v.v" en in gevalle waar valse vriende op grond van hoë gebruiksfrekwensie as "gevaarlik" beskou word, word 'n uitroepteken bygevoeg soos vir bakkie in (18).

(19)

\begin{tabular}{|c|c|c|c|}
\hline DUTCH & AFRIKAANS & DUTCH & AFRIKAANS \\
\hline vaak ' 'often' & dikwels & bestellen & \\
\hline \multirow[t]{2}{*}{ vaak ${ }^{2}$ 'sleepy' } & vaak & 1 'to order' & bestel \\
\hline & & 2 'to deliver' & aflewer \\
\hline
\end{tabular}

Gouws et al. (2004: 800, 802)

Gevalle waar sowel betekenisooreenkomste as -verskille vir ' $n$ bepaalde lemma voorkom, word nie in ANNA as valse vriende hanteer nie. Martin (2012b: 421) hou tergen/terg as tipiese voorbeeld voor waar belangrike verskille slegs deur 'n opmerking ondersteun word.

\section{(20)}

tergen ww.tr., terg ww.tr. \{Opm.: Hoewel 'terg' in Afr. ook wel 'treiter' kan beteken, word dit oor die algemeen minder sterk gebruik as in Ned. en beteken dit eerder skertsend as gemeen pla.\}

A $\mid \mathrm{N}$ (sarren) terg, tart, treiter = iemand op alle mogelijk manieren tergen iemand op alle moontlike maniere tart $\neq$ graag terg graag plagen; veral Amsterdammers kan ongenadig terg 
vooral Amsterdammers kunnen geweldig zuigen; iemand terg omdat hy vet is iemand plagen omdat hij dik is

Eerder as om op die verskille te konsentreer met betrekking tot valse vriende, verwys hy na hierdie benadering as 'n poging om weg te beweeg van verskille en beskou dit as deel van die newe-effekte van die geamalgameerde sisteem. Trouens, Martin (2012b: 420-421) verwys daarna met die sterk term "slaggate" in die sisteem:

More serious perhaps than the system side effects ... which ... can be overcome by the system, are, what I call, pitfalls. ... cases where there is a meaning overlap or minor meaning/usage differences between Afrikaans and Dutch. As a rule, in ANNA, we have chosen to abstract away from these differences, in other words, to 'lump', not to 'split', quite in line with the amalgamation approach itself.

Al drie die gevalle bakkie/bakkie, bestellen/bestel en vaak/vaak wat in Gouws et al. (2004) voorgehou word, en eersgenoemde selfs as gevaarlike valse vriend, word in ANNA gevolglik nie as valse vriende hanteer nie en ressorteer in dieselfde kategorie as tergen/terg, naamlik die benadering waarvolgens daar "weg van die verskille geabstraheer word" en die verskille as gewone betekenisse bewerk word. Vergelyk byvoorbeeld die artikels van bakkie/bakkie, vaak/vaak en bestellen/bestel in (21).

bakkie nw. [het; mv: -s], bakkie nw. [mv: -s]

A|N (verkleinwoord v. 'bak') bakkie

$\mathrm{N}$ - (27mc-zender) radiosender

(2) (aanhangwagentje) oop sleepwaentjie agter 'n motor

o (kopje koffie) koppie koffie

A (ligte vragmotor) pick-up, kleine open bestelauto

(2) (soort roeibootjie) roeibootje

vaak $^{1}$ b.nw.

A (slaperig) slaperig $\neq$ vaak word slaap krijgen; vaak wees slaap hebben vaak $^{2}$ nw. [de; mv: -], vaak nw. [mv: -]

$\mathrm{A} \mid \mathrm{N}<\mathrm{BN}>$ (slaperig gevoel) vaak $=<$ fig. $>$ praatjies voor de vaak praatjies vir die vaak $\neq$ vaak hebben vaak wees $\neq<$ fig.> Klaas Vaak Klaas Vakie, sandmannetjie $\neq$ deur die vaak oorval word door de slaap overvallen worden

vaak $^{3}$ bw.

$\mathrm{N}$ (veelal, in de meeste gevallen) dikwels, baiekeer, baiemaal = we sijn vaak te laat voor de opening ons is dikwels te laat vir die opening $\neq$ het gebeurt steeds vaker dit gebeur steeds meer dikwels, dit gebeur al hoe meer; let wel op want de ruit is al vaak genoeg gebroken wees versigtig, want die ruit is al dikwels genoeg gebreek; hij ging vaak bij haar op bezoek hy het baiekeer by haar gaan kuier

bestel nw. [het; mv: -], bestel nw. [mv: -]

AIN (organisatie) bestel, bedeling = het publieke bestel die publieke bestel

bestellen ww.tr., bestel ww.tr.

A|N O (laten komen) bestel = een boek/trui/biertje bestellen ' $n$ boek/trui/biertje bestel; een 
taxi bestellen ' $n$ taxi bestel $\neq$ kos/drank/bestel voedsel/drank laten aanrukken

(2) ((van post aan huis bezorgen) bestel = een telegram/een brief bestellen ' $n$ telegram/

' $n$ brief bestel $=<$ fig. $>$ een overledene ter aarde bestellen ' $n$ oorledende ter aarde bestel

Die vraag is dus of bakkie/bakkie, vaak/vaak en bestellen/bestel sonder meer as valse vriende getipeer en bewerk moet word of alternatiewelik soos enige ander polisemiese lemma behandel moet word met byvoeging van addisionele gebruikersleiding soos in (20).

Daar kan geargumenteer word dat in geval van enige vorm van valse vriende dit belangrik is om die gebruiker bedag te maak op die verskille sodat die woorde nie verkeerd gebruik word nie.

Dit moet egter duidelik gestel word dat die bewerking van sulke gevalle in ANNA voldoende inligting aan die gebruiker bied al word hulle nie eksplisiet as valse vriende gemerk deur die woordeboek se konvensie "!!" nie. Die vraag is net of die gebruiker vaardig genoeg sal wees om uit (20) te konkludeer dat die hoofbetekenis van tergen deur byvoorbeeld provokeer weergegee kan word, terwyl terg met pla gedefinieer kan word. Wat gevalle soos bakkie/bakkie, vaak/vaak en bestellen/bestel betref, is die vraag of geamalgameerde woordeboeke die gebruiker nie meer eksplisiet bedag moet maak op veral "gevaarlike" valsevriende-verhoudings nie.

\section{'n Afsonderlike grammatikale kompendium}

Daar kan met die intrapslag gevra word of dit werklik nodig is om ' $n$ sogenaamde grammatikale kompendium as ' $n$ afsonderlike teks aan te bied. Uit ' $n$ sekere hoek beskou, is dit nie in die gees van amalgamering waar die onderliggende filosofie juis die reduksie van twee (of meer) lemmalyste tot 'n enkele lemmalys is nie. Tweedens is dit op verskeie vlakke gebruikersonvriendelik. Gebruikers wat normaalweg nie aandag aan die agtertekste in woordeboeke gee of die gebruiksinligting noukeurig lees nie, sal nie eers besef dat daar so ' $n$ gedeelte bestaan nie. Dit kan vererger word deur die feit dat die bestaan van die kompendium nie prominent genoeg bekendgestel word nie of selfs moontlik dat gebruikers die begrip kompendium self nie verstaan nie, soos inderdaad blyk uit die gebruikerstudie van Bosman (2013).

Die Nederlandse frase wat 'n kruisverwysing na die agtertekste bevat, zie compendium, is nie deur die studente verstaan nie of bloot geïgnoreer. Respondent $\mathrm{B}$ het byvoorbeeld gedink dit is 'n vertaalekwivalent vir die Afrikaanse woord is. ... 'n Ernstiger probleem is dat die frase zie compendium wat gebruikers na hierdie agterteks verwys, hoegenaamd nie in die gebruiksaanwysings verduidelik word nie. (Bosman 2013: 49)

Dit is onwaarskynlik dat veral onervare teikengebruikers sal weet dat voorsetsels, telwoorde, voegwoorde, voornaamwoorde en lidwoorde funksiewoorde is. Selfs al sou die teikengebruikers dit weet, is dit onwaarskynlik dat hulle 
lemmas soos diegene, genoeg, iemand en minder as funksiewoorde sal herken wat in 'n afsonderlike lys opgesoek moet word. Dit geld veral dié woorde wat, benewens as funksiewoorde, ook as ander woordsoorte optree, en wat, soos wat ANNA daarna verwys, in die "eintlike woordeboekgedeelte" aangebied word. So, byvoorbeeld, is die kans gering dat die gebruiker sal weet om genoeg as bywoord in die hoofteks op te soek maar as voornaamwoord in die kompendium. Net so is dit onwaarskynlik dat hy/sy die kennis het om minder as byvoeglike naamwoord en ook as bywoord in die hoofteks op te soek maar as telwoord in die kompendium. Die gebruiker sal gevolglik eers via kruisverwysings by die lemmas uitkom, wat verhoging in inligtingskoste impliseer. Die afsonderlike kompendium verswaar dus die mediostruktuur en veroorsaak dat gebruikers meer in die woordeboek moet rondblaai. In die geval van genoeg en minder, byvoorbeeld, is die kruisverwysing duidelik: genoeg ${ }^{2}$ vnw. zie compendium. Die kruisverwysing is minder gebruikersvriendelik as die gebruiker byvoorbeeld by wil opsoek, vergelyk (22):

by $^{1}$ nw. zie bij nw.

by $^{2}$ voors. zie bij

by- zie (ook) bij-

Die gebruiker wat nie weet dat voorsetsels in die kompendium opgeneem word nie, word nie ingelig dat $\mathbf{b y}^{2}$ in die compendium opgeneem en bewerk is nie. Hy/sy sal stellig eers na bij in die hoofteks gaan waar $\mathbf{b i j}$ as naamwoord en werkwoord bewerk word met 'n kruisverwysing: bij ${ }^{3}$ voorz. zie compendium. Hoewel die soektog uiteindelik suksesvol is, is die inligtingskoste hoog.

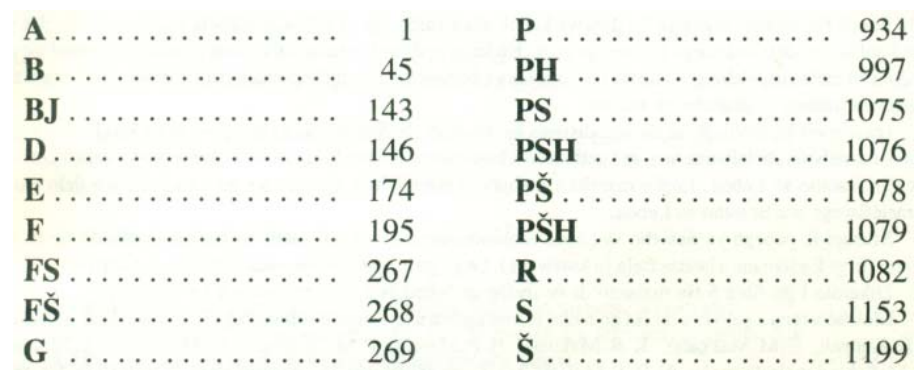

Die leksikograaf het dikwels 'n moeilike keuse tussen 'n leksikografiese benadering wat "linguisties meer korrek" of die "beste opsie" is en 'n benadering wat minder akkuraat, maar meer gebruikersvriendelik is. 'n Tipiese voorbeeld wat groot gebruikersfrustrasie tot gevolg het, is die Groot Noord-Sotho Woordeboek (GNSW) waar die samestellers afgewyk het van 'n normale alfabetiese ordening ten gunste van 'n fonetiese ordening omdat laasgenoemde na hulle mening grammaties meer korrek is. Dit het onder meer tot gevolg dat lemmas 
wat met $b u$ - begin voor lemmas wat met $b j$ - begin in die alfabetiese lys aangegee word. Hierdie benadering noodsaak dat 'n spesiale blad voor in die woordeboek geraadpleeg moet word alvorens die gemiddelde en selfs gevorderde gebruiker woorde kan opsoek. Vergelyk (23) wat 'n uittreksel uit die alfabetiese gids is.

\section{Samevatting en aanbevelings}

Dit kan onomwonde gestel word dat die geamalgameerde model, en ANNA in besonder, ongeëwenaard is wat betref die inligtingswaarde ten opsigte van vergelyking en kontrastering van twee of meer verwante tale. Die woordeboek slaag uitnemend in die sistematiese en konsekwente aanbieding van sodanige ooreenkomste en verskille in al die kognaatkategorieë wat vir ANNA onderskei word. Dit is in dié opsig ' $n$ uitstekende inligtingsbron.

Die voordele van 'n geamalgameerde woordeboek moet egter opgeweeg word teen ' $n$ aantal moontlike negatiewe aspekte. Eerstens is 'n mate van redundansie onvermydelik as gevolg van die behoefte aan kruisverwysings ten opsigte van die kompendium, asook minstens in kategorieë (b) en (d), waar 'n aparte lemma vir die ander lid van die taalpaar gegee moet word in die toepaslike alfabetiese posisie ten einde die gebruiker te lei na die lemma waar die nodige inligting gevind kan word.

Tweedens lei 'n geamalgameerde benadering tot relatief lang(er) artikels bloot omdat behandeling in dieselfde artikel aangebied word vir twee of meer tale (drie in die geval van die Sothotale en selfs vier vir die Ngunitale). Dit beteken dat die gebruiker langer inskrywings moet deurwerk om die inligting te bekom waarna hy/sy op soek is. Die deurlees van langer artikels staan in teenstelling tot huidige tendense in die leksikografie om te waak teen oormatige inligtingsaanbod en die gebruiker meer direk te lei na die presiese verlangde inligting. Vergelyk byvoorbeeld Prinsloo et al. (2011) waar gebruikers deur keuse-boomstrukture direk na die juiste inligting gelei word.

Derdens kan geredeneer word dat in teenstelling met die A/N-gedeelte in ' $n$ gegewe woordeboekartikel, die afsonderlike A- en N-gedeeltes nie bydra tot ruimtebesparing in vergelyking met afsonderlike Afrikaans-Nederlandse en Nederlands-Afrikaanse woordeboeke of woordeboekdele nie.

' $n$ Vierde veronderstelde voordeel van ANNA is dat dit geskik is as 'n leeswoordeboek, dit wil sê dat gebruikers dit sal lees vir ontspanning. Dit is te betwyfel en sal deur gebruikerstudies bevestig moet word.

Die geamalgameerde benadering tot die samestelling van woordeboeke het besliste voordele maar ook sekere beperkinge wat in hierdie artikel as inligtingskoste en sisteemkoste voorgehou is. Die leksikograaf moet deurgaans probeer om die voordele van die model maksimaal te benut en geen steen onaangeroer laat om die beperkinge van die benadering te minimaliseer nie. Dit is veral aspekte van gebruikersvriendelikheid wat besondere aandag moet geniet. Beperkinge wat toegeskryf kan word aan inherente eienskappe van die model 
of, volgens Martin (2012b), gegewe newe-effekte of slaggate van die sisteem, kan nie almal sonder meer besweer word nie. Die leksikograaf moet egter daarna streef om dié tipes inligtings- en sisteemkoste uit te weer wat onnodig negatief op gebruikersvriendelikheid inwerk. In beginsel moet hy/sy dus ' $n$ onderskeid maak tussen inherente sisteemeienskappe en -beperkings versus dit waaraan die leksikograaf wel iets kan doen.

'n Eerste stap kan wees om omvattende gebruikersinligting saam te stel, soos wat dit voortreflik in ANNA gedoen is en dan die inligting te stratifiseer deur middel van ' $n$ enkelblad-gebruikersgids heel voor in die woordeboek. ' $n$ Tweede stap is die oordrag van inligting aan die gebruiker ten opsigte van die algemene aard van die woordeboek, die amalgamasiemodel, die tipes trefwoorde, bou en struktuur van die artikels, behandeling van voorbeelde en verbindings, verwysings, agtertekste, ens. 'n Derde vlak kan meer inligting rakende die inherente kenmerke van die sisteem soos die aanbod en ordening van ekwivalente en betekenisonderskeidings verskaf. Samestellers van geamalgameerde woordeboeke kan dit selfs oorweeg om 'n demonstrasie van die gebruik in een of ander elektroniese formaat by die papier- sowel as elektroniese weergawe in te sluit. Soos wat dit vir die samestelling van gebruikersgidse in enige woordeboek geld, moet die leksikograaf seker maak dat daar veral nie foute in rigtinggewende voorbeelde in die gebruikersgids is nie.

Geamalgameerde lemmalyste noodsaak wel afsonderlike lemmatisering van sekere kategorieë van woorde soos niekognate en kognate met 'n vormverskil. Hier moet die mediostruktuur die gebruiker lei na die korrekte lemma waar ' $n$ bewerking aangebied word. Dit is belangrik dat die leksikograaf konsekwent sal hou by die redaksionele beleid soos in die gebruikersleiding aangedui is, byvoorbeeld die verstekreël "groter as sewe" wat in ANNA gebruik word. Hierbenewens moet versigtige oorweging gegee word aan die teikengebruiker se vermoë om die verband tussen vormlik verwante lemmas te kan insien. Indien die leksikograaf enigsins twyfel, kan 'n ad hoc-besluit geneem word om sekere woorde in die teikentaal of -tale te lemmatiseer.

Ten opsigte van vertaalekwivalente en die ordening van betekenisse behoort samestellers dit sterk te oorweeg om vertaalekwivalente en betekenisonderskeidings wat die hoofbetekenis of mees frekwente betekenisonderskeiding in die teikentaal verwoord, maar nie eerste aangebied kan word nie, op een of ander wyse as sodanig te markeer.

Samestellers kan verder meer aandag gee aan valse vriende-verhoudings by polisemiese lemmas en dit oorweeg om dié verhoudings baie duidelik te markeer of die betrokke lemmas formeel as valse vriende te bewerk.

Die leksikograaf moet die voor- en nadele van 'n afsonderlike kompendium vir funksiewoorde in geamalgameerde woordeboeke krities teen mekaar opweeg en besluit of dit nie meer gebruikersvriendelik sal wees om met 'n enkele geamalgameerde lemmalys te volstaan nie. Dit sou dan steeds moontlik wees om, indien nodig, funksiewoorde op een of ander gepaste wyse te markeer. 
Ten slotte kan gesê word dat ten spyte van sekere tekortkominge inherent aan die amalgamasiebenadering, ANNA 'n woordeboek van hoë leksikografiese prestasie is en 'n monument vir die Afrikaanse en Nederlandse leksikografie!

\section{Acknowledgement}

This work is based on the research supported in part by the National Research Foundation of South Africa (Grant specific unique reference number (UID) 85763).

The Grantholder acknowledges that opinions, findings and conclusions or recommendations expressed in any publication generated by the NRF supported research are those of the author, and that the NRF accepts no liability whatsoever in this regard.

\section{Verwysings}

\section{Woordeboeke}

ANNA $=$ Martin, Willy (Hoofred.). 2011. Pharos Groot Woordeboek. Afrikaans en Nederlands (Prisma Groot Woordenboek Afrikaans en Nederlands). Kaapstad: Pharos.

e-HAT = Odendal, F.F. en R.H. Gouws. Verklarende Handwoordeboek van die Afrikaanse Taal. Vyfde uitgawe op CD ROM. 2005. Kaapstad: Pearson.

GNSW = Ziervogel, D. and P.C. Mokgokong. 1975. Pukuntšu ye kgolo ya Sesotho sa Leboa, Sesotho sa Leboa-Seburu/Seisimane/Groot Noord-Sotho-woordeboek, Noord-Sotho-Afrikaans/Engels/Comprehensive Northern Sotho Dictionary, Northern Sotho-Afrikaans/English. Pretoria: J.L. van Schaik.

Hartmann, R.R.K. en G. James. 1998. Dictionary of Lexicography. Londen/New York: Routledge.

Van Dale Groot Woordenboek op CD ROM = Van Dale Groot Woordenboek Hedendaags Nederlands. Versie 2.0. 2002. Van Dale Lexicografie bv. Utrecht/Antwerpen. Zocksoftware 2002. C-Content, Rosmalen.

\section{Ander literatuur}

Bosman, Nerina. 2013. Die gebruik van ANNA in 'n Nederlandse taalverwerwingskursus - toegangsgemak en inligtingskoste. Botha, W., P. Mavoungou en D. Nkomo. 2013. Festschrift RUFUS H. GOUWS: 39-54. Stellenbosch: SUN PReSS.

Cognitive Overhead, Or Why Your Product Isn't As Simple As You Think. Lieb, David = http://techcrunch. com/2013/04/20/cognitive-overhead/. (Geraadpleeg 22 Mei 2013).

Gouws, R.H., D.J. Prinsloo en G.-M. de Schryver. 2004. Friends will be Friends - True or False. Lexicographic Approaches to the Treatment of False Friends. Williams, G. en S. Vessier (Reds.). 2004. Proceedings of the Eleventh EURALEX International Congress, EURALEX 2004, Lorient, France, July 6-10, 2004: 797-805. Lorient: Faculté des Lettres et des Sciences Humaines, Université de Bretagne Sud. 
Marais, R. 2011. Een mooie dikke dame. "ANNA", het Groot Woordenboek Afrikaans en Nederlands. Ons Erfdeel 1: 190-192.

Martin, Willy en Rufus Gouws. 2000. A New Dictionary Model for Closely Related Languages: The Dutch-Afrikaans Dictionary Project as a Case in Point. Heid, Ulrich, Stefan Evert, Egbert Lehmann en Christian Rohrer (Reds.). 2000. Proceedings of the Ninth EURALEX International Congress, 8-12 August 2000: 783-792. Stuttgart: Institut für Maschinelle Sprachverarbeitung, Universität Stuttgart.

Martin, W. 2012a. Amalgamated Bilingual Dictionaries. Genis, René et al. (Reds.). 2012. Between East and West. Festschrift for Wim Honselaar on the Occasion of his 65th Birthday. Pegasus OostEuropese Studies 20: 437-449. Amsterdam: Uitgeverij Pegasus.

Martin, W. 2012b. ANNA: A Dictionary with a Name (and what Lies Behind it). Lexikos 22: 406-426.

Media24 Argief: Beeld = http://152.111.1.88/cgi-bin/beeld.cgi (Geraadpleeg 6 Mei 2013).

Prinsloo, D.J. 2006. Compiling a Bidirectional Dictionary Bridging English and the Sotho Languages: A Viability Study. Lexikos 16: 193-204.

Prinsloo, Danie J., Ulrich Heid, Theo J.D. Bothma and Gertrud Faaß. 2011. Interactive, Dynamic Electronic Dictionaries for Text Production. Kosem, I. and K. Kosem (Reds.). 2011. Electronic Lexicography in the 21st Century. New Applications for New Users. Proceedings of eLex 2011, Bled, 10-12 November 2011: 215-220. Bled: Trojína. 